\title{
Bibliography of Secondary Sources
}

Albury, William, "The Order of Ideas: Condillac's method of analysis as a political instrument in the French Revolution," John Schuster and R.R. Yeo, eds., The Politics and Rhetoric of Scientific Method: Historical studies (Dordrecht: Reidel Publishing Co., 1986), 203-225.

Alder, Ken, "A Revolution to Measure: The political economy of the metric system in France," M. Norton Wise, ed., Values of Precision (Princeton: Princeton University Press, 1995), 39-71.

Alder, Ken, Engineering the Revolution: Arms and enlightenment in France, 1763-1815 (Princeton: Princeton University Press, 1999).

Alder, Ken, "Innovation and Amnesia: Engineering rationality and the fate of interchangeable parts manufacturing in France," Technology and Culture 38 (1997): 273-311.

Algazi, Gadi, “Scholars in Households: Refiguring the learned habitus, 1480-1550," Science in Context 16 (2003): 9-42.

Allchin, Douglas, “James Hutton and Coal," Cadernos IG/UNICAMP 7 (1997): 167-183.

Allen, Tim, Mike Cotterill, Geoffrey Pike, “The Kentish Copperas Industry," Archeologia Cantiana, 122 (2002), 319-334.

Amin, Wahida, "The Poetry and Science of Humphry Davy," PhD Thesis, University of Salford, 2013.

Anderson, R.G.W., "A Source for Eighteenth Century Chemical Glass," Georgi Dragoni, Anita McConnell and Gerard L'E. Turner, eds., Proceedings of the Eleventh International Scientific Commission Symposium (Bologna: Grafis Edizioni, 1994): 47-52.

Anderson, R.G.W., "Chemistry Beyond the Academy: Diversity in Scotland in the early nineteenth century," Ambix 57 (2010): 84-103.

Anderson, R.G.W., The Playfair Collection and the Teaching of Chemistry at the University of Edinburgh, 1713-1858 (Edinburgh: Royal Scottish Museum, 1978).

Anderson, R.G.W., "Thomas Charles Hope and the Limiting Legacy of Joseph Black," R.G.W., Anderson, ed., Cradle of Chemistry: The early years of chemistry at the University of Edinburgh (Edinburgh: John Donald, 2015), 147-162.

Anderson, R.G.W., "What is Technology?: Education through museums in the midnineteenth century," British Journal for the History of Science 25 (1992): 169-84.

Anderson, R.G.W., and Jones, Jean, eds., The Correspondence of Joseph Black, 2 vols., (Farnham: Ashgate, 2012).

Anderson, Stuart, ed., Making Medicines: A brief history of pharmacy and pharmaceuticals (London: Pharmaceutical Press, 2005).

Anes, Gonzalo, Economía e ilustración en la España del siglo XVIII (Barcelona: Ariel, 1969). Anon., Howards, 1797-1947 (Ilford: Howards \& Sons, 1947). 
Arber, E.A. Newell, The Natural History of Coal (Cambridge: Cambridge University Press, 1911).

Archer, Mary, and Christopher D. Haley, The 1702 Chair of Chemistry at Cambridge: Transformation and change (Cambridge: Cambridge University Press, 2005).

Arkestijn, N.L.M., "Met de bajonet op de keel. Inkopen met ongedekt papiergeld," E.H.P. Cordfunke and H. Sarfatij, eds., Van Solidus tot euro: Geld in Nederland in economisch-historisch en politiek perspectief (Hilversum: Verloren, 2004), 139-146.

Arnold, David, Toxic Histories. Poison and pollution in modern India (Cambridge: Cambridge University Press, 2016).

Ashbee, Ruth, "The Discovery of Chlorine: A window to the chemical revolution," Hasok Chang and Catherine Jackson, eds., An Element of Controversy: The life of chlorine in science, medicine, technology, and war (London: British Society for the History of Science, 2007), 15-40.

Ashworth, William J. "Between the Trader and the Public': British alcohol and the proof of good governance," Technology and Culture 42 (2001): 27-50.

Ashworth, William J. Customs and Excise: Trade, production and consumption in England, 1640-1845 (Oxford: Oxford University Press, 2003).

Ashworth, William J. "Quality and the Roots of Manufacturing 'Expertise' in EighteenthCentury Britain," Osiris 25 (2010): 231-254.

Ashworth, William J. "The British Industrial Revolution and the Ideological Revolution: Science, neoliberalism and history," History of Science $5^{2}$ (2014): 178-199.

Ashworth, William J. "The Ghost of Rostow: Science, culture and the British Industrial Revolution," History of Science 46 (2008): 250-274.

Ashworth, William J. "The Intersection of Industry and the State in Eighteenth Century Britain," Lissa Roberts, Simon Schaffer and Peter Dear, eds., The Mindful Hand: Inquiry and invention from the late renaissance to early industrialisation (Amsterdam: Edita, Royal Netherlands Academy of Sciences, 2007), 348-77.

Atkins, Peter, Liquid Materialities. A history of milk, science and the law (Surrey: Ashgate, 2010).

Aymes, Jean René, España y la revolución francesa (Barcelona: Crítica, 1989).

Bada, Juan, "Don Pedro Díaz de Valdés, obispo de Barcelona (1798-1807)," Anthologica Anпиа 19 (1972): 651-674.

Baker, Keith M., Condorcet: From natural philosophy to social mathematics (Chicago: University of Chicago Press, 1974).

Baker, Keith M. and William A. Smeaton, "The Origins and Authorship of the Educational Proposals Published in 1793 by the Bureau de Consultation des Arts et Métiers and generally Ascribed to Lavoisier," Annals of Science 21 (1965): 33-46.

Ball, Michael and David Sunderland, An Economic History of London, 1800-1914 (London: Routledge, 2001). 
Balland, Antoine, Les pharmaciens militaires français (Paris: Imprimerie-librairie militaire universelle L. Fournier, 1913).

Balz, Viola, Heiko Stoff, Alexander v. Schwerin and Bettina Wahrig, eds., Precarious Matters. The history of dangerous and endangered substances in the nineteenth and twentieth centuries (Berlin: Max Planck Institute, 2008).

Barillé, Claire, Thomas Le Roux and Marie Thébaud-Sorger, “Grenelle, 1794. Secourir, indemniser et soigner les victimes d'une catastrophe industrielle à l'heure révolutionnaire," Le Mouvement Social 249 (2014): 41-71.

Barker, Richard, "French Entrepreneurship During the Restoration: The record of a single firm, the Anzin Mining Company," The Journal of Economic History 21 (1961): 161-178.

Barles, Sabine, L'invention des déchets urbains: France, 1790-1970 (Seyssel: Champ Vallon, 2005).

Barles, Sabine, La Ville Délétère. Médecins et ingénieurs dans l'espace urbain, XVIIIe-XIXe siècles (Seyssel: Champvallon, 1999).

Barrenechea, José Manuel, Valentín de Foronda, reformador y economista ilustrado (Álava: Diputación Foral, 1984).

Bartrip, Peter, “A 'Pennurth of Arsenic for Rat Poison': The Arsenic Act (1851) and the prevention of secret poisoning," Medical History 36 (1992): 53-69.

Beale, Norman and Elaine Beale, Echoes of Ingen Housz: The long lost story of the genius who rescued the Habsburgs from smallpox and became the father of photosynthesis (East Knoyle: Hobnob Press, 2011).

Beek, Marcel van der, “'s Rijks Munt en de aanmuntingen door De Heus," De Beeldenaar 2 (1995): 357-366.

Belhoste, Bruno, La Formation d'une technocratie. L'École polytechnique and ses élèves de la Révolution au Second Empire (Paris: Belin, 2003).

Belhoste, Jean-François and Woronoff, Denis, "Ateliers et manufactures : Une réévaluation nécessaire," Françoise Monnier, ed., A Paris sous la Révolution, nouvelles approches de la ville (Paris: Publications de la Sorbonne, 2008), 79-91.

Jones, Henry Bence, The Royal Institution: Its founders, and its first professors (London: Longman, 1871).

Bensaude Vincent, Bernadette, "Between Chemistry and Politics: Lavoisier and the Balance," Eighteenth Century, Essays and Interpretation 33 (1992): 217-237.

Bensaude Vincent, Bernadette, "Chemistry as a Technoscience," Jean-Pierre Llored, ed., The Philosophy of Chemistry:Practices, methodologies, and concepts (Newcastle-uponTyne: Cambridge Scholars Publishing , 2013), 330-341.

Bensaude Vincent, Bernadette, Lavoisier. Mémoires d'une révolution (Paris: Flammarion, 1993).

Bensaude Vincent, Bernadette and Christine Blondel, eds., Science and Spectacle in the European Enlightenment (London: Ashgate Publishing, 2005). 
Bensaude Vincent, Bernadette and Ferdinando Abbri, eds, Lavoisier in European Context. Negotiating a new language for chemistry (Sagamore Beach: Science History Publications, 1995).

Bensaude Vincent, Bernadette and Agustí Nieto Galán, "Theories of Dyeing: A view on the long-standing controversy through the works of Jean-Francois Persoz," Robert Fox and Agustí Nieto Galán, eds., Natural Dyestuffs and Industrial Chemistry in England, 1750-1880 (Canton, MA: Science History Publications, 1999), 3-24.

Bensaude Vincent, Bernadette and Isabelle Stengers, Histoire de la chimie (Paris: La Découverte, 1993).

Beretta, Marco, "Pneumatic vs. 'Aerial Medicine': Salubrity and respirability of air at the end of the eighteenth century," Nuova Voltiana: Studies on Volta and his time 2 (2000): 49-71.

Beretta, Marco, The Definition of Chemistry from Agricola to Lavoisier. Uppsala Studies in History of Science, 15 (Sagamore Beach: Science History Publications, 1993).

Beretta, Marco, The Enlightenment of Matter (Sagamore Beach: Science History Publications, 1993).

Berman, Alex, "J.B.A. Chevallier, Pharmacist-Chemist : A major figure in nineteenthcentury French public health," Bulletin for the History of Medecine $5^{2}$ (1978): 200-213.

Berman, Morris, Social Change and Scientific Organization: The Royal Institution, 17991844 (Ithaca: Cornell University Press, 1978).

Bernal, J.D., Science in History, 4 vols. (Harmondsworth: C.A. Watts, 1965).

Bertomeu Sánchez, José R., and Antonio García Belmar, “Pedro Gutiérrez Bueno (17451822) y las relaciones entre la química y la farmacia durante el último tercio del siglo XVIII," Hispania 208 (2001): 539-562.

Bertomeu Sánchez, José Ramón, "Animal Experiments, Vital Forces and Courtrooms: Mateu Orfila, François Magendie and the study of poisons in nineteenth-century France," Annals of Science 69 (2012):1-26.

Bertomeu Sánchez, José Ramón, "Classrooms, Salons, Academies and Courts: Mateu Orfila (1787-1853) and nineteenth-century French toxicology," Ambix 61 (2014): 162-186.

Bertomeu Sánchez, José Ramón, "Managing Uncertainty in the Academy and the Courtroom: Normal arsenic and nineteenth-century toxicology," Isis 104 (2013): 197-225.

Bertomeu Sánchez, José Ramón, "Smell, Chemistry and Microscopy: Bloodstains and nineteenth-century forensic medicine," Annals of Science 72 (2015): 490-516.

Bertomeu Sánchez, José Ramón, La verdad sobre el caso Lafarge. Ciencia, justicia y ley durante el siglo XIX (Barcelona: El Serbal, 2015).

Bertomeu Sánchez, José Ramón and Agustí Nieto Galán, eds., Chemistry, Medecine and Crime. Mateu J.B. Orfila (1787-1853) and his times (Sagamore Beach: Science History Publications, 2006). 
Bertomeu Sánchez, José Ramón and Antonio García Belmar, "Louis Jacques Thenard's Chemistry Courses at the Collège de France, 1804-1835," Ambix 57 (2010): 48-63.

Bickerton, David and René Sigrist, eds., Marc-Auguste Pictet 1752-1825: Correspondance, sciences et techniques. Tome III: Les correspondants britanniques (Geneva: Slatkine, 2000).

Blanckaert, Claude, Michel Porret, eds., L'Encyclopédie méthodique, 1782-1832. Des Lumières au positivisme (Genève: Librairie Droz, 2006).

Blow, Simon, Broken Blood: The rise and fall of the Tennant Family (London: Faber and Faber, 1987).

Blussé, Leonard, Visible Cities. Canton, Nagasaki, and Batavia and the coming of the Americans (Cambridge: Harvard University Press, 2008).

Bödeker, Hans Erich, "Economic Societies in Germany, 1760-1820: Organization, social structures and fields of activities, "Koen Stapelbroek and Jani Marjanen, eds., The Rise of Economic Societies in the Eighteenth Century (London: Palgrave MacMillan, 2012), 182-211.

Boegheim, L.M.J., "François Loriaux, de stichter van de Duitenmunt te Soerabaja," De Beeldenaar 3 (1996): 131-134.

Bonastra, Quim, "Los orígenes del lazareto pabellonario. La arquitectura cuarentenaria en el cambio del setecientos al ochocientos," Asclepio 60 (2008): 60-61.

Bonnassieux, Pierre, Conseil de commerce et bureau du commerce 1700-1791. Inventaire analytique des procès-verbaux (Paris: Imprimerie nationale, 1900).

Boomgaard, Peter, ed., Empire and Science in the Making. Dutch colonial scholarship in comparative global perspective, 1760-1830 (New York: Palgrave Macmillan, 2013).

Bosma, Ulbe, The Sugar Plantation in India and Indonesia. Industrial production, 1770-2010 (Cambridge: Cambridge University Press, 2013).

Boudia, Soraya and Nathalie Jas, eds., special issue, "Risk and Risk Society in Historical Perspective," History and Technology 23 (2007).

Bourquelot, Émile, Le centenaire du Journal de pharmacie et de chimie (1809-19o9) (Paris: Octave Doin et fils, 1910).

Bouvet, Maurice, “Nicolas Vauquelin, droguiste," Revue d'histoire de la pharmacie 46 (1958): 246-252.

Bowden, Witt, Industrial Society in England Towards the End of the Eighteenth Century, second edition (London: Frank Cass \& Co., 1965).

Bray, Francesca, Technology, Gender and History in Imperial China: Great transformations reconsidered (London; New York: Routledge, 2013).

Bret, Patrice, "Des essais de la Monnaie à la recherche et à la certification des métaux: un laboratoire modèle au service de la guerre et de l'industrie (1775-1830)," Annales historiques de la Révolution Française 320/2 (2000): 137-148.

Bret, Patrice, L'Etat, l'armée, la science. L'invention de la recherche publique en France, 1763-183o (Rennes: Presses Universitaires de Rennes, 2002). 
Brewer, John, The Sinews of Power: War, money, and the English State, 1688-1783 (Cambridge: Harvard University Press, 1988).

Brewer, John and Roy Porter, Consumption and the World of Goods (New York: Routledge, 1993).

Brock, William H., Justus von Liebig: The chemical gatekeeper (Cambridge: Cambridge University Press, 1997).

Brose, Eric Dorn, The Politics of Technological Change in Prussia: Out of the shadow of antiquity, 1809-1848 (Princeton: Princeton University Press, 1993).

Brown, Chandos Michael, Benjamin Silliman: A life in the young republic (Princeton, NJ: Princeton University Press, 2014).

Bucknill, John, The Coins of the Dutch East Indies (London: Spink, 1931).

Burnby, J., "The Early Years of the Pharmaceutical Industry," Lesley Richmond, Julie Stevenson and Alison Turton, eds., The Pharmaceutical Industry: A guide to historical records (Aldershot: Ashgate, 2003), 1-13.

Burney, Ian, "Languages of the Lab: Toxicological testing and medico-legal proof," Studies in History and Philosophy of Science 33 (2002): 289-314.

Burney, Ian, Poison, Detection, and the Victorian Imagination (Manchester: University Press, 2006).

Butt, John, John Anderson's Legacy: The University of Strathclyde and its antecedents (East Linton: Tuckwell Press, 1996).

Callon, Michel, "What Does it Mean to Say that Economics is Performative?," csI Working Papers Series 5 (2006).

Callon, Michel and Vololona Rabeharisoa, "Research "In the Wild" and the Shaping of New Social Identities," Technology in Society 25 (2003): 193-204.

Cameron, Rondo, "A New View of European Industrialization," The Economic History Review 38 (1985): 1-23.

Campbell, R.H., A.S. Skinner and W.B. Todd, eds., The Glasgow Edition of the Works and Correspondence of Adam Smith (Oxford: Clarendon Press, 1976).

Cannadine, David, "The Present and the Past in the English Industrial Revolution, 18801980," Past and Present 103 (1984): 131-172.

Cantlie, Neil, A History of the Army Medical Department, vol. 1 (London and Edinburgh: Churchill Livingstone, 1974).

Cardwell, Donald, "Ure, Andrew," Oxford Dictionary of National Biography (Oxford: Oxford University Press, 2004).

Carrasco Jarabo, Paula, "Vida y obra de Pedro Gutiérrez Bueno" Boletín de la Sociedad Española de Historia de la Farmacia 15 (1964):154-69; 16 (1965):10-24; 71-86; 101-18 and $153-77$.

Carrillo, Juan L., Juan Manuel de Aréjula (1755-1830). Estudio sobre la fiebre amarilla (Madrid: Ministerio de Sanidad y Consumo, 1986). 
Carrillo, Juan L., Pedro Riera Perelló and Ramón Gago, "La introducción en España de las hipótesis miasmática y prácticas fumigatorias. Historia de una polémica (J.M Aréjula - M.J Cabanellas)," Medicina e historia 67 (1977): 8-26.

Carrillo, Juan L., Jesús Castellanos and María Dolores Ramos, Enfermedady sociedad en la Málaga de comienzos del siglo XIX: El diálogo de los muertos en la epidemia de Málaga (c.1803) (Málaga: Universidad de Málaga, 1980).

Carrillo, Juan L., and L. García Ballester, "El comportamiento de las clases y grupos sociales de Málaga en las epidemias de fiebre amarilla," Cuadernos de la historia de la medicina española, 11 (1972): 88-95.

Cassin, Barbara, ed., Dictionary of Untranslatables: A philosophical lexicon (Princeton: Princeton University Press, 2014).

Chakrabarti, Pratik, "Empire and Alternatives: Swietenia febrifuga and the cinchona substitutes," Medical History 54 (2010): 75-94.

Chakrabarti, Pratik, Materials and Medicine: Trade, conquest and therapeutics in the eighteenth century (Manchester: Manchester University Press, 2010).

Chambers, Neil, ed., The Scientific Correspondence ofJoseph Banks, 6 volumes (London: Pickering, 2007).

Chandler, Alfred, "Anthracite Coal and the Beginnings of the Industrial Revolution in the United States," Business History Review 46 (1972): 141-181.

Chang, Hasok, and Catherine Jackson, eds., An Element of Controversy: The life of chlorine in science, technology, medicine and war (Oxford: British Society for the History of Science, 2007).

Chauvaud, Frédéric, Experts et expertise judiciaire : France, XIXe et XXe siècles (Rennes : PUR, 2003).

Chauvaud, Frédéric, Les experts du crime. La médecine légale en France au XIXè siècle (Paris: Aubier, 2000).

Clarke, Adele and Joan Fujimura, eds., The Right Tools for the Job (Princeton: Princeton University Press, 1992).

Claver, Alex, Dutch Commerce and Chinese Merchants in Java. Colonial relationships in trade and finance, 1800-1942 (Brill: Leiden, 2014).

Clow, Archibald and Nan Clow, The Chemical Revolution: A contribution to social technology (London: Batchwork Press, 1952).

Cockayne, Emily, Hubbub: Filth, noise and stench in England, 160o-1770 (New Haven:Yale University Press, 2007).

Coggan, Philip, Paper Promised: Debt, money and the new world order (New York, NY: Public Affairs, 2012).

Cohen, I. Bernard, Revolution in Science (Cambridge, MA: Harvard University Press, 1985).

Cook, Harold J. and Timothy D. Walker, "Circulation of Medicine in the Early Modern Atlantic World," Social History of Medicine 26 (2013): 337-51. 
Cooper, Alix, "Homes and Households," Katharine Park and Lorraine Daston, eds., The Cambridge History of Science, Vol. 3: Early Modern Science (Cambridge: Cambridge University Press, 2006), 224-237.

Cooper, Denis R., The Art and Craft of Coinmaking. A history of minting technology (London: Spink \& Son 1988).

Cooper, Timothy, "Peter Lund Simmonds and the Political Ecology of Waste Utilization in Victorian Britain," Technology and Culture $5^{2}$ (2011): 21-44.

Cooter, Roger and Stephen Pumfrey, "Separate Spheres and Public Places: Reflections on the history of science popularization and science in popular culture," History of Science 32 (1994): 237-267.

Corbin, Alain, Le miasme et la jonquille. L'odorat et l'imaginaire social, XVII-XIXe siècles (Paris: Aubier, 1982).

Corvol, Andrée, transl. by Richard C. Holbrook, "The Forest," Pierre Nora and David P. Jordan, eds., Rethinking France:Les lieux de mémoire, vol. 2, Space (Chicago: University of Chicago Press, 2006).

Crawforth, Michael A., Weighing Coins: English folding gold balances of the eighteenth and nineteenth centuries (London: Cape Horn Trading, 1979).

Crosland, Maurice, "Slippery Substances'. Some practical and conceptual problems in the understanding of gases in the pre-Lavoisier era," Frederic L. Holmes and Trevor H. Levere, eds., Instruments and Experimentation in the History of Chemistry (Cambridge: MIT Press, 2000), 79-89.

Crouzet, François, The First Industrialists: The problem of origins (Cambridge: Cambridge University Press, 1985).

Cullen, William R., Is Arsenic an Aphrodisiac? The sociochemistry of an element (Cambridge: RSC, 2008)

Curth, Louise Hill, ed., From Physick to Pharmacology: Five hundred years of British drug retailing (Aldershot: Ashgate, 2006).

Cushman, Gregory, Guano and the Opening of the Pacific World: A global ecological history (Cambridge: Cambridge University Press, 2013).

Dalmasso, Gilbert, "Présence de la 'chymie' dans la France du Nord de la deuxième moitié du XVIII ${ }^{\mathrm{e}}$ siècle au premier tiers du XIX ${ }^{\mathrm{e}}$ siècle," PhD Thesis, Université de Lille III, 2005.

Darnton, Robert, Mesmerism and the End of the Enlightenment in France (Cambridge, MA: Harvard University Press, 1968).

Darnton, Robert, The Business of Enlightenment (Cambridge: Harvard University Press, 1979).

Darnton, Robert, The Forbidden Bestsellers of Pre-Revolutionary France (New York: W.W. Norton and Co., 1996).

Daston, Lorraine, ed., Biographies of Scientific Objects (Chicago: University Press, 200o). 
Daston, Lorraine, ed., L'économie morale des sciences modernes (Paris : La Découverte, 2014).

Daston, Lorraine, ed., "The Moral Economy of Science," Osiris 10 (1995): 2-24.

Daston, Lorraine, ed., Things That Talk. Object Lessons from Art and Science (New York: Zone Books, 2008).

Daumas, Maurice, Les instruments scientifiques aux XVII et XVIII siècles (Paris: Presses Universitaires de France, 1953).

Dauphin, Alain and Dominique Pradeau, eds., La pharmacie hospitalière dans les hôpitaux de Paris (Reims: Imprimerie Sogedic-Landais, 1995).

Davies, Timothy, "British Private Trade Networks and Metropolitan Connections in the Eighteenth Century," Maxine Berg, ed., Goods from the East, 1600-180o:Trading Eurasia (Basingstoke: Palgrave Macmillan, 2015), 154-167.

Davison, Luke Antony Francis, "Raising up Humanity: A cultural history of rescucitation and the Royal Humane Society of London, 1774-1808," PhD thesis, University of York, 2001.

Davy, John, Memoirs of the Life of Sir Humphry Dary, Bart, 2 volumes (London: Longman, 1836).

Deforges, Yves, Le graphisme technique. Son histoire et son enseignement (Seyssel: Champ Vallon, 1981).

Delépine, Marcel, “Joseph Pelletier and Joseph Caventou," Journal of Chemical Education 28 (1951): 454-461.

Deligeorges, Stéphane, Alexandre Gady and Françoise Labalette, Le jardin des plantes et le Muséum national d'histoire naturelle (Paris: Monum, 2004).

Denys, Catherine, Police et Sécurité au XVIIIe siècle dans les Villes de la frontière FrancoBelge (Paris: L'Harmattan, 2002).

Devaux, Guy, «Marchands de mort-aux-rats,» Revue d'histoire de la pharmacie 92 (2004): 509-516.

Dhombres, Jean, and Nicole Dhombres, Naissance d'un nouveau pouvoir: Sciences et savants en France, 1793-1824 (Paris: Payot, 1989).

Diederiks, H.A., "Hendrik de Heus. Een Amsterdamse ondernemer in het begin van de 19e eeuw," Amstelodamum 56 (1969): 58-65.

Dillemann, Georges, "Les établissements d'enseignement pharmaceutique de 1803 à 1994," Annales pharmaceutiques françaises 53 (1995) : 1-7.

Dillemann, Georges, ed., La faculté de pharmacie de Paris, 1882-1982 (Paris: Éditions Comarco, 1982).

Douglas, Susan J, "Some Thoughts on the Question 'How Do New Things Happen?" Technology and Culture 51 (2010): 293-304.

Drayton, Richard, Nature's Government: Science, imperialism, and the "improvement" of the world (New Haven: Yale University Press, 2000). 
Driel, Joppe van, "Ashes to Ashes: The stewardship of waste and oeconomic cycles of agricultural and industrial improvement, 1750-1800," History and Technology 30 (2014): 177-206.

Driel, Joppe van, "The Filthy and the Fat: Oeconomy, chemistry and resource management in the age of revolution," PhD Thesis, University of Twente, 2016.

Driel, Joppe van and Lissa Roberts, "Circulating Salts: Chemical governance and the bifurcation of 'nature' and 'society', Eighteenth-Century Studies 49 (2016): 233-263.

Durie, Alastair J., The Scottish Linen Industry in the Eighteenth Century (Edinburgh:John Donald, 1979).

Dutton, Harold Irvin, "The Patent System and Inventive Activity During the Industrial Revolution (1750-1852)," PhD Thesis, London University, 1981.

Dyer, G.P. and P.P. Gaspar, "Reform, the New Technology and Tower Hill, 1700-1966," C.E. Challis ed., A New History of the Royal Mint (Cambridge: Cambridge University Press, 1992), 398-6o6.

Ecole normale supérieure, Le livre du centenaire. Edition du bicentenaire (Paris: Presses de l'École normale supérieure, 1994).

Eddy, Matthew D., "The Sparkling Nectar of Spas; or, Mineral water as a medically commodifiable material in the province, 1770-1805," Ursula Klein and Emma Spary, eds., Materials and Expertise in Early Modern Europe: Between market and laboratory (Chicago: University of Chicago Press, 2010), 283-292.

Edgerton, David, Shock of the Old: Technology and global history since 1900 (London: Profile Books, 2006).

Ellis, Kenneth, The Post Office in the Eighteenth Century: A study in administrative history (Oxford: Oxford University Press, 1958).

Elmpt, Theo van, Netherlands East Indies. Paper currency, 1815-1827 (Uithoorn: Elran Express, 2009).

Elson, Robert E., “The Floracrats (book review)," American Historical Review 116 (2011): 1469 .

Emerson, Roger and Paul Wood, "Science and Enlightenment in Glasgow, 1690-1802," Charles Withers and Paul Wood, eds., Science and Medicine in the Scottish Enlightenment (East Linton: Tuckwell Press, 2002), 79-142.

Erikson, Emily, Between Monopoly and Free Trade: The English East India Company, 160o1757 (Princeton: Princeton University Press, 2014).

Ewing, Heather, The Lost World of James Smithson: Science, revolution, and the birth of the Smithsonian (New York: Bloomsbury, 2007).

Faure, Henri, Histoire de la céruse depuis l'antiquité jusqu'aux temps modernes (Lille: Levebvre-Ducrocq, 1889).

Fichter, James R., So Great a Proffit. How the East India trade transformed Anglo-American capitalism (Cambridge: Harvard University Press, 2010).

Fisher, George Park, Life of Benjamin Silliman M.D., LL.D., 2 vols. (New York, 1866). 
Fissell, Mary E., Patients, Power, and the Poor in Eighteenth Century Bristol (Cambridge, Cambridge University Press, 1991).

Forbes, John S., Hallmark. A history of the London Assay Office (London: The Goldsmith's Company, 1999).

Forgan, Sophie, ed., Science and the Sons of Genius: Studies on Humphry Davy (London, Science Reviews, 1980).

Fors, Hjalmar, "The Knowledge and Skill of Foreigners: Projectors and experts at the early modern Swedish Board of Mines," Hartmut Schleiff and Peter Konečný, eds., Staat, Bergbau und Bergakademie im 18. und frühen 19. Jahrhundert (Stuttgart: vswG, 2012), 53-62.

Fors, Hjalmar, The Limits of Matter: Chemistry, mining and enlightenment (Chicago: University of Chicago Press, 2015).

Foster, John Bellamy, "Marx's Theory of Metabolic Rift: Classical foundations for environmental sociology," American Journal of Sociology 105 (1999): 366-405.

Foucault, Michel, Naissance de la biopolitique, Cours au Collège de France 1978-1979 (Paris: Gallimard Seuil Haute études, 2004).

Fox, Robert, The Caloric Theory of Gases from Lavoisier to Regnault (Oxford: Oxford University Press, 1971).

Frangsmyr, Tore, J.L. Heilbron, and Robin E. Rider, eds., The Quantifying Spirit in the Eighteenth Century (Berkeley: University of California Press, 1990).

Frank, Lawrence, Victorian Detective Fiction and the Nature of Evidence: The scientific investigations of Poe, Dickens, and Doyle (London: Palgrave, 2003).

Fressoz, Jean-Baptiste, L'apocalypse joyeuse. Une histoure du risque technologique (Paris: Le Seuil, 2012).

Friedman, Georges, "L'Encyclopédie et le travail humain," Annales, histoire, sciences sociales 8 (1953): 53-68.

Frindlund, Mats, "Affording Terrorism: Idealists and materialities in the emergence of modern terrorism," Max Taylor and P.M. Currie, eds., Terrorism and Affordance (London: Continuum, 2012), 73-92.

Fritschy, Wantje, De patriotten en de financiën van de Bataafse Republiek. Hollands krediet en de smalle marges voor een nieuw beleid (1795-1801) ('s-Gravenhage: Stichting Hollandse Historische Reeks, 1988).

Fujii, Kiyohisa, “The Berthollet-Proust Controversy and Dalton's Atomic Theory, 18001820," British Journal for the History of Science 19 (1986): 177-200.

Fullmer, J.Z., "Technology, Chemistry, and the Law in Early 19th-century England," Technology and Culture 21 (1980): 1-28.

Fullmer, June, "Humphry Davy: Fund raiser," Frank A.J.L. James, ed., The Development of the Laboratory: Essays on the place of experiment in industrial civilisation (London: Macmillan, 1989), 11-21. 
Fullmer, June, Sir Humphry Davy's Published Work (Cambridge, MA: Harvard University Press, 1969).

Fullmer, June, Young Humphry Davy: The making of an experimental chemist (Philadelphia: American Philosophical Society, 2000).

Galbraith, John, "The 'Turbulent Frontier' as a Factor in British Expansion," Comparative Studies in Society and History 2 (1960): 150-168.

García Ballester, Luis and Juan L. Carrillo "The Repression of Medical Science in Absolutism Spain: The case of Juan Manuel de Aréjula, 1755-1830", Clio Medica 9 (1974): 207-211.

García Ballester, Luis and Juan L. Carrillo "Un ejemplo de represión de la ciencia en la España absolutista: La supresión del capitulo 15 de la 'Breve descripción de la fiebre amarilla' (1806) de J.M. Arejula," Revista de Occidente 134 (1974): 205-11.

García Belmar, Antonio, “The Didactic Use of Experiment: Louis-Jacques Thenard's lectures at the Collège de France," José Ramón Bertomeu Sánchez and Agustí Nieto Galán, eds., Chemistry, Medecine and Crime.MateuJ.B. Orfila (1787-1853) and his times (Sagamore Beach : Science History Publications, 2006), 25-53.

García Belmar, Antonio and José R. Bertomeu Sánchez, "Pedro Gutiérrez Bueno, los libros de texto de química, y los nuevos públicos de la química en el último tercio del siglo XVIII," Dynamis 2 (2001): 351-74.

García Belmar, Antonio, "España fumigada. Consensos y silencios en torno de las fumigaciones ácido-minerales en España, 1770-1804," (in progress).

García Belmar, Antonio, “Louis Jacques Thenard's chemistry courses at the Collège de France, 1804-1835," Ambix 57 (2010): 48-63.

Garnier, Arthur Edmund, The Chronicles of the Garniers of Hampshire during Four Centuries, 1530-1900 (Norwich and London: Jarrold and Sons, 1900).

Gee, Brian, and William H. Brock, "The Case of John Joseph Griffin: From artisan-chemist and author-instructor to business leader," Ambix 38 (1991): 29-62.

Geiger, Reed G., The Anzin Coal Company 1800-1833: Big business in the early stages of the French industrial revolution (Newark: University of Delaware Press, 1974).

Gieryn, Thomas F., "Boundary-Work and the Demarcation of Science from Non-Science: Strains and interests in professional ideologies of scientists," American Sociological Review 48 (1983): 781-795.

Gillipsie, Charles Coulston, Science and Polity in France. The end of the old regime (Princeton: Princeton University Press, 1980).

Gillipsie, Charles Coulston, Science and Polity in France: The revolutionary and Napoleonic years (Princeton: Princeton University Press, 2004).

Gillipsie, Charles Coulston, "Science in the French Revolution," Proceedings of the National Academy 45 (1959): 677-84.

Gillipsie, Charles Coulston, The Edge of Objectivity: An Essay in the History of Scientific Ideas (Princeton: Princeton University Press, 1966). 
Gillipsie, Charles Coulston, The Montgolfier Brothers and the Invention of Aviation, 17831784 (Princeton: Princeton University Press, 1983).

Gillispie, Charles C. and Ken Alder, “Exchange: Engineering the Revolution,” Technology and Culture 39 (1998): 733-54.

Golinski, Jan, British Weather and the Climate of Enlightenment (Chicago: University Of Chicago Press, 2011).

Golinski, Jan, "Chemistry," Roy Porter, ed., The Cambridge History of Science: Volume 4, eighteenth-century science (Cambridge: Cambridge University Press, 2003), 375396.

Golinski, Jan, "Conversations on Chemistry: Talk about phlogiston in the coffee house society, 1780-1787," Trevor H. Levere and Gerard L'Estrange Turner, eds., Discussing Chemistry and Steam: the minutes of a coffee house philosophical society, 1780-1787 (Oxford: Oxford University Press, 2002), 191-205.

Golinski, Jan, “Fit Instruments': Thermometers in eighteenth-century chemistry," Frederic L. Holmes and Trevor H. Levere, eds., Instruments and Experimentation in the History of Chemistry (Cambridge: The MIT Press, 2000), 185-210.

Golinski, Jan, "Humphry Davy: The experimental self," Eighteenth-Century Studies 45 (2011): 15-28.

Golinski,Jan, "Precision Instruments and the Demonstrative Order of Proof in Lavoisier's Chemistry," Osiris 9 (1994): 30-47.

Golinski, Jan, Science as Public Culture: Chemistry and Enlightenment in Britain, 1760-1820 (Cambridge: Cambridge University Press, 1992).

Gooday, Graeme, "Placing or Replacing the Laboratory in the History of Science?" Isis 99 (2008): 783-795.

Gooding, David, “'In Nature's School': Faraday as an experimentalist," David Gooding and Frank James, eds., Faraday Rediscovered; Essays on the life and work of Michael Faraday, 1791-1867 (London: Macmillan, 1985), 105-136.

Goss, Andrew, The Floracrats. State-sponsored science and the failure of enlightenment in Indonesia (Madison: University of Wisconsin Press, 2011).

Graaf, Ton de, Voor handel en Maatschappij. Geschiedenis van de Nederlandsche HandelMaatschappij, 1824-1964 (Boom: Amsterdam, 2012).

Granjel, Luis, Historia de la Real Academia Nacional de Medicina de Madrid (Madrid: Real Academia Nacional de Medicina, 2006).

Grapi, Pere and Mercé Izquierdo, "Berthollet's Conception of Chemical Change in Context," Ambix 44 (1997): 113-130.

Griffin, Emma, A Short History of the Industrial Revolution (London: Palgrave, 2010).

Guerlac, Henry, Lavoisier - The Crucial Year: The background and origin of his first experiments on combustion in 1772 (Ithaca: Cornell University Press, 1961).

Guerrini, Anita, “The Ghastly Kitchen," History of Science 54 (2016): 78-104. 
Guignard, Laurence, Juger la folie. La folie criminelle devant les Assises au XIXe siècle (Paris: PUF, 2010).

Guignard, Léon, ed., Centenaire de l'École supérieure de pharmacie de l'Université de Paris, 1803-1903 (Paris: A. Joanin, 1904).

Guillerme, André, "Enclosing Nature in the City: Supplying light and water to Paris, 1770-1840," Construction History 26 (2011): 79-93.

Guillerme, André, La naissance de l'industrie à Paris entre sueurs et vapeurs (1780-1830) (Paris: Champ Vallon, 2007).

Haan, Frederik de, “Personalia der periode van het Engelsch bestuur over Java 1811-1816," Bijdragen tot de Taal-, Land-en Volkenkunde in Nederlandsch-Indië 92 (1935): 477-681.

Hamlin, Christopher, "The City as a Chemical System? The chemist as urban environmental professional in France and Britain, 1780-1880," Journal of Urban History 33 (2007): 702-728.

Hamlin, Christopher, A Science of Impurity: Water analysis in nineteenth-century Britain (Berkeley, CA: University of California Press, 1990).

Hamlin, Christopher, "State Medicine in Britain," Dorothy Porter, ed., The History of Public Health and the Modern State, (Amsterdam: Rodopi, 1994), 132-164.

Harkness, Deborah E. "Managing an Experimental Household: The Dees of Mortlake and the practice of natural philosophy," Isis 88 (1997):247-262.

Harris, Frances, "Living in the Neighbourhood of Science: Mary Evelyn, Margaret Cavendish and the Greshamites," Lynette Hunter and Sarah Hutton, eds., Women, Science, and Medicine 1500-1700: Mothers and sisters of the Royal Society (Stroud:Sutton Publishing, 1997), 198-217.

Harvey, Karen, The Little Republic: Masculinity and domestic authority in eighteenthcentury Britain (Oxford: Oxford University Press, 2012).

Haudricourt, André-George, La technologie, science humaine. Recherche d'histoire et d'ethnologie des techniques (Paris: Maison des sciences de l'homme, 1987).

Hembry, Phyllis, The English Spa 1560-1815: A social history (London: Athlone, 1990).

Hentschel, Klaus, Mapping the Spectrum: Techniques of visual representation in research and teaching (Oxford: University Press, 2002).

Hentschel, Klaus, Visual Cultures in Science and Technology (Oxford: Oxford University Press, 2014).

Hilaire Pérez, Liliane, "Invention and the State in Eighteenth-Century France," Technology and Culture 32/3 (1991): 911-31.

Hilaire Pérez, Liliane, L'invention technique au siècle des Lumières (Paris: Albin Michel, 2000).

Hilaire Pérez, Liliane, La pièce et le geste. Artisans, marchands et culture technique à Londres au XVIIIe siècle (Paris: Albin Michel, 2013). 
Hilaire Pérez, Liliane, "Technical Invention and Institutional Credit in France and Britain in the Eighteenth Century," History and Technology 16 (2000): 295-306.

Hilaire Pérez, Liliane and Marie Thébaud Sorger, "Les techniques dans l'espace public. Publicité des inventions et littérature d'usage au XvıIIe siècle (France, Angleterre)," Revue de Synthèse 127 (2006): 393-428.

Hobhouse, Hermione, ed., Survey of London: Volumes 43 and 44, Poplar, Blackwall and Isle of Dogs (London: London County Council, 1994).

Hobsbawm, E.J., The Age of Revolution: Europe 1789-1848 (London: Weidenfeld and Nicholson, 1962).

Hoitsema, Copius and F. Feith, De Utrechtsche munt uit haarverleden en heden (Utrecht: Oosthoek, 1912).

Holloway, S.W.F., Royal Pharmaceutical Society of Great Britain, 1841-1991: A political and social history (London: The Pharmaceutical Press, 1991).

Holmes, Frederic L., Eighteenth-century Chemistry as an Investigative Enterprise (Berkeley, CA: Office for History of Science and Technology, University of California at Berkeley, 1989).

Holmes, Frederic L. and Trevor H. Levere eds., Instruments and Experimentation in the History of Chemistry (Cambridge, Mass.; London, England: MIT Press, 2000).

Homburg, Ernst, "The Rise of Analytical Chemistry and its Consequences for the Development of the German Chemical Profession," Ambix 46 (1999): 1-32.

Homburg, Ernst and de Vlieger, Johan H., "A Victory of Practice over Science: Failed innovations in the white lead industry (1780-1850)," Archives internationales d'histoire des sciences 46 (1996): 95-112.

Horn,Jeff, "Privileged Enclaves: Opportunities in eighteenth-century France," Proceedings of the Western Society for French History 32 (2004): 29-45.

Horn, Jeff, The Path not Taken: French industrialization in the age of revolution, 1750-1830 (Cambridge, MA: Miт Press, 2006).

Horn, Jeff, Leonard N. Rosenband and Merritt Roe Smith, Reconceptualizing the Industrial Revolution (Cambridge, MA: MIT Press, 2010).

Hudson, Pat, The Industrial Revolution (London: Bloomsbury, 2014).

Hufbauer, Karl, The Formation of the German Chemical Community 1720-1795 (Berkeley, CA: University of California Press, 1982).

Hughes, Thomas P., American Genesis: A century of invention and technological enthusiasm, 1870-1970 (Chicago/London: The University of Chicago Press, 2004, first published in 1989).

Hughes, Thomas P., "The Evolution of Large Technological Systems," Wiebe E. Bijker, Thomas P. Hughes, and Trevor J. Pinch eds., The Social Construction of Technological Systems: New directions in the sociology and history of technology (Cambridge, Mass: MIT Press, 1987), 51-82. 
Hunting, Penelope, A History of the Society of Apothecaries (London: Society of Apothecaries, 1998).

Hurlbert, William Henry, France and the Republic (Charleston: BiblioLife, 2007 [1890]). Hutchby, Ian, "Affordances and the Analysis of Technologically Mediated Interaction," Sociology 37 (2003): 581-89.

Hutchby, Ian, "Technologies, Texts, and Affordances," Sociology 35 (2001): 441-56.

Ingold, Tom, "Materials Against Materiality," Archeological Dialogues 14 (2007): 1-16.

Isoré, Jacques, "De l'existence des brevets d'invention en droit français avant 1791," Revue historique de droit français et étranger 16 (1937): 94-130.

Jackson, Catherine M., "The 'Wonderful Properties of Glass': Liebig's kaliapparat and the practice of chemistry in glass," Isis 106 (2015): 43-69.

Jackson, Roland, "John Tyndall and the Early History of Diamagnetism," Annals of Science 72 (2015): 435-489.

Jacob, Margaret, The First Knowledge Economy: Human capital and the European economy, 1750-1850 (Cambridge: Cambridge University Press, 2014).

Jacob, Margaret C. and Larry Stewart, Practical Matter: Newton's science in the service of industry and empire (Cambridge, MA: Harvard University Press, 2004).

James, Frank A.J.L., “'Agricultural Chymistry is at present in it's infancy': The Board of Agriculture, the Royal Institution and Humphry Davy," Ambix 62 (2015): 363-385.

James, Frank A.J.L., ed., 'The Common Purposes of Life': Science and society at the Royal Institution of Great Britain (Aldershot: Ashgate, 2002).

James, Frank A.J.L., 'the first example ... of an extensive scheme of pure scientific medical investigation': Thomas Beddoes and the Medical Pneumatic Institution in Bristol, 1794 to 1799 (London: Royal Society of Chemistry Historical Group Occasional Publication, 2016).

James, Frank A.J.L., Michael Faraday: A very short introduction (Oxford: Oxford University Press, 2010).

James, Frank A.J.L. and Anthony Peers, "Constructing Space for Science at the Royal Institution of Great Britain," Physics in Perspective 9 (2007): 130-185.

Jankovic, Vladimir, Confronting the Climate. British air and the making of environmental medicine (New York: Palgrave Macmillan, 2010).

Jas, Nathalie, "Public Health and Pesticide Regulation in France Before and After Silent Spring," History and Technology 23 (2007): 369-388.

Jay, Mike, The Atmosphere of Heaven: The unnatural experiments of Dr. Beddoes and his sons of genius (New Haven: Yale University Press, 2009).

Jenner, Mark and Patrick Wallis, "The Medical Marketplace," Mark Jenner and Patrick Wallis, eds., Medicine and the Market in England and its Colonies, c.1450-c.185o (London: Palgrave Macmillan, 2007), 1-17.

Jensen, William B., "Machael Faraday and the Art and Science of Chemical Manipulation," Bulletin for the History of Chemistry 11 (1991): 65-75. 
Johnston, Kenneth, Unusual Suspects: Pitt's reign of alarm and the lost generation of the 179os (Oxford: Oxford University Press, 2013).

Johnston, W.T., The Secret of Turkey Red (Livingston: Officina W.T. Johnston, 1993).

Jones, Jean, “James Hutton and the Forth and Clyde Canal," Annals of Science 39 (1982): $255^{-263 .}$

Jones, Jean, “James Hutton's Agricultural Research and his Life as a Farmer," Annals of Science 42 (1985): 573-601.

Jones, Peter M., Industrial Enlightenment: Science, technology and culture in Birmingham and the West Midlands, 1760-1820 (Manchester: Manchester University Press, 2009).

Jones, Peter M., The Peasantry in the French Revolution (Cambridge: Cambridge University Press, 1988).

Jonker, J. and K.E. Sluyterman, At Home on the World Markets: Dutch international trading companies from the sixteenth century until the present (The Hague: SDU Uitgevers, 2000).

Julia, Dominique, "L'Ecole normale de l'an III : bilan d'une expérience révolutionnaire”, Revue du Nord 78 (1996): 853-886.

Julien, Pierre, "Plaidoyer pour les notes et factures anciennes de pharmacie," Revue d'histoire de la pharmacie 37 (1990) : 81-92.

Jungnickel, Christa and Russell McCormmach, Cavendish: The experimental life (Lewisburg: Bucknell, 1998).

Keay, John, The Honorable Company: A history of the English East India Company (London: Harper Collins, 1991).

Kemp, Pieter Hendrik van der, "De Nederlandsche-Indische proefgulden van 1815," Tijdschrift voor munt- en penningkunde (1913): 21-6o.

Kemp, Pieter Hendrik van der, "De zilveren Java-Ropijen van de jaren 1816-1817," Bijdragen tot de Taal-, Land- en Volkenkunde van Nederlandsch-Indië 67 (1913):275-366.

Kemp, Pieter Hendrik van der, "Episodes uit de geschiedenis der aanmuntingen ten behoeve van Oost-Indië, 1802-1807," Bijdragen tot de taal-, land-en volkenkunde van Nederlandsch-Indië 70 (1915): 227-440.

Kemp, Pieter Hendrik van der, De teruggave der Oost-Indische koloniën 1814-1816 ('s-Gravenhage: M. Nijhoff, 1910).

Kent, Andrew, ed., An Eighteenth Century Lectureship in Chemistry: Essays and addresses relating to the chemistry department of Glasgow University (Glasgow: Jackson Son \& Co., 1950).

Kersaint, Georges, "L'usine de Fourcroy et Vauquelin," Revue d'Histoire de la Pharmacie 47 (1959): 25-30.

Kian, Kwee H., "The Expansion of Chinese Inter-insular and Hinterland Trade in Southeast Asia, c. 1400-1850," David Henley and Henk Schulte Nordholt, eds., Environment, Trade and Society in Southeast Asia (Brill: Leiden, 2015), 149-165.

Kim, Mi Gyung, Affinity: That elusive dream (Cambridge, MA: MIT Press, 2003). 
Kinzler, Catherine, Condorcet. L'instruction publique et la naissance du citoyen (Paris: Folio/Essais, 1984).

Klein, Cornelia and Anthony Philpotts, Earth Materials: Introduction to mineralogy and petrology (Cambridge: Cambridge University Press, 2013).

Klein, Ursula, "Apothecary Shops, Laboratories and Chemical Manufacture in Eighteenth-century Germany," Lissa Roberts, Simon Schaffer and Peter Dear, eds., The Mindful Hand: Inquiry and invention from the late Renaissance to early industrialisation (Amsterdam: Royal Netherlands Academy of Arts and Sciences, 2007), 247-278.

Klein, Ursula, "Apothecary-Chemists in Eighteenth Century Germany," Lawrence Principe, ed., New Narratives in Eighteenth-Century Chemistry (Dordrecht: Springer, 2007), 97-137.

Klein, Ursula, ed., Artisanal-Scientific Experts in Eighteenth-Century France and Germany, special issue of Annals of Science 69 (2012): 303-433.

Klein, Ursula, "Blending Technical Innovation and Learned Natural Knowledge: The making of ethers," Ursula Klein and Emma Spary, eds., Materials and Expertise in Early Modern Europe: Between market and laboratory (Chicago: University of Chicago Press, 2010), 125-157.

Klein, Ursula, "Chemical Experts at the Royal Prussian Porcelain Manufactory," Ambix 60 (2013): 99-121.

Klein, Ursula, Experiments, Models, Paper Tools: Cultures of organic chemistry in the nineteenth century (Palo Alto: Stanford University Press, 2002).

Klein, Ursula, "The Laboratory Challenge: Some revisions of the standard view of early modern experimentation," Isis 99 (2008): 769-782.

Klein, Ursula, “The Prussian Mining Official Alexander von Humboldt," Annals of Science 69 (2012): 27-68.

Klein, Ursula, "A Revolution that Never Happened," Studies in History and Philosophy of Science 49 (2015): 80-90.

Klein, Ursula, "Technoscience avant la lettre," Perspectives on Science 13 (2005): 226-266.

Klein, Ursula and Carsten Reinhardt, eds., Objects of Chemical Inquiry (Sagamore Beach, MA: Science History Publications, 2014).

Klein, Ursula and Emma Spary, eds., Materials and Expertise in Early Modern Europe: Between market and laboratory (Chicago: Chicago University Press, 2010).

Klein, Ursula and Wolfgang Lefèvre, Materials in Eighteenth-Century Science: A historical ontology (Cambridge, MA: MIT Press, 2007).

Kneitz, Agnes, "'As if the River was not Meat and Drink to You': Social novels as a means of framing nineteenth-century environmental justice," Interdisciplinary Studies in Literature and Environment 1 (2015): 1-16. 
Knight, David, Humphry Davy: Science and power (Oxford: Blackwell, 1992; Second Edition, Cambridge: Cambridge University Press, 1996).

Knight, Roger, "Rescued from the Myths of Time: Toward a reappraisal of European merchant houses in mid-nineteenth century Java, ca. 1830-1870," Bijdragen tot de Taal,- Land- en Volkenkunde 170 (2014): 313-341.

Knight, Roger and Malcolm Wilcox, Sustaining the Fleet, 1793-1815: War, the British Navy and the contractor state (Woodbridge: Boydell Press, 2010).

Knorr Cetina, Karin, “Objectual practice," T.R. Schatzki, K. Knorr Cetina, \& E. von Savigny, eds., The Practice Turn in Contemporary Theory (New York: Routledge, 2001), 184-197.

Knox, Kevin C. “'The Deplorable Frenzy': The slow legitimisation of chemical practice at Cambridge University," Mary D. Archer, Christopher D. Haley, eds., The 1702 Chair of Chemistry at Cambridge: Transformation and Change (Cambridge: Cambridge University Press, 2005), 1-30.

Konečný, Peter, “The Hybrid Expert in the 'Bergstaat': Anton von Ruprecht as a professor of chemistry and mining and as a mining official, 1779-1814," Annals of Science 69 (2012): 335-347.

Kranakis, Eda, Constructing a Bridge: An exploration of engineering culture, design and research in nineteenth-century France and America (Cambridge MA: MIT Press, 1997).

Kranakis, Eda, "Hybrid Careers and the Interaction of Science and Technology,"

Peter Kroes and Martijn Baker, eds., Technological Development and Science in the Industrial Age (Dordrecht: Kluwer Academic Publishers, 1992), 177-204.

Laissus, Yves, Le Muséum national d'histoire naturelle (Paris: Gallimard, 1995).

Lantink, Frans Willem et al., Voor stad en staat, vol. 1: Plattegrond (Amsterdam: Joh. Enschedé, 2003).

Laparra López, Emilio, La Alianza de Godoy con los revolucionarios (Madrid: Consejo Superior de Investigaciones Científicas, 1992).

Laparra López, Emilio, "Ilustrados e Inquisición ante la Iglesia constitucional francesa," Revista de Historia das Ideias 10 (1988): 359-374.

Laparra López, Emilio, "La inestabilidad de la monarquía de Carlos IV," Studia Histórica. Historia moderna 12 (1994): 23-34.

Lavoisy, Olivier and Dominique Vinck, "Le dessin comme objet intermédiaire de l'industrie," Pierre Delcambre, ed., Communications organisationnelles. Objets, pratiques et dispositifs (Rennes: Presses Universitaires de Rennes, 2000), 47-63.

Law, John and Vicky Singleton, “Object Lessons,” Organization 12 (2005): 331-355.

Le Roux, Thomas, "Accidents industriels et régulation des risques: l'explosion de la poudrerie de Grenelle en 1794," Revue d'Histoire Moderne et Contemporaine 58-3 (2011): $34-62$.

Le Roux, Thomas, "Chemistry and Industrial and Environmental Governance in France, 1770-1830," History of Science 54 (2016): 195-222. 
Le Roux, Thomas, "La chimie, support du développement de l'industrie perfectionnée sous la Révolution et l'Empire," Natacha Coquery, ed., Les progrès de l'industrie perfectionnée (Toulouse: Presses universitaires du Mirail, 2017), 26-35.

Le Roux, Thomas, “Déclinaisons du 'conflit'. Autour des atteintes environnementales de l'affinage des métaux précieux, Paris, années 1820," Thomas Le Roux and Michel Letté, eds., Débordements industriels dans la cité et leurs conflits, XVIII-XXIe siècles (Rennes: Presses Universitaires de Rennes, 2013), 179-198.

Le Roux, Thomas, "Guyton de Morveau et le grand basculement de l'expertise sanitaire et environnementale (1773-1809)," Annales Historiques de la Révolution française 383 (2016): 153-176.

Le Roux, Thomas, Le laboratoire des pollutions industrielles, Paris, 1770-1830 (Paris: Albin Michel, 2011).

Le Roux, Thomas, "Risques et maladies du travail: Le Conseil de salubrité de Paris aux sources de l'ambiguïté hygiéniste au Xıx ${ }^{\mathrm{e}}$ siècle," Anne-Sophie Bruno, Éric Geerkens, Nicolas Hatzfeld and Catherine Omnès, eds., La santé au travail, entre savoirs et pouvoirs (XIX ${ }^{e}-X X^{e}$ siècles) (Paris: Presses universitaires de Rennes, 2011), 45-63.

Lehman, Christine, "Innovation in Chemistry Courses in France in the Mid-Eighteenth Century : Experiments and affinities," Ambix 57 (2010) :3-26.

Lehman, Christine, "Les multiples facettes des cours de chimie en France au milieu du XVIII ${ }^{\mathrm{e}}$ siècle,» Histoire de l'éducation 130 (2011) : 31-56.

Leong, Elaine, "Collecting Knowledge for the Family: Recipes, gender and practical knowledge in the early modern English household," Centaurus 55 (2013): 81-103.

Leong, Elaine, "Making Medicines in the Early Modern Household," Bulletin of the History of Medicine 82 (2008): 145-168.

Leroi-Gourhan, André, L'Homme et la Matière (Paris: Albin Michel, 1943).

Lestel, Laurence, Anne-Cécile Lefort and André Guillerme, eds., La céruse: usages et effets $X^{e}-X X^{e}$ siècles (Paris: Centre d'histoire des techniques CNAM, 2003).

Levere, Trevor H., "Dr. Thomas Beddoes and the Establishment of His Pneumatic Institution: A tale of three presidents," Notes and Records of the Royal Society of London 32 (1977): 41-49.

Levere, Trevor H., "Dr. Thomas Beddoes at Oxford: Radical politics in 1788-1793 and the fate of the Regius Chair in Chemistry," Ambix 28 (1981): 61-69.

Levere, Trevor H., "Measuring Gases and Measuring Goodness," Frederic Lawrence Holmes and Trevor H. Levere, eds., Instruments and Experimentation in the History of Chemistry (Cambridge: Cambridge University Press, 2000), 105-136.

Levere, Trevor H., "The Role of Instruments in the Dissemination of the Chemical Revolution," Endoxa 19 (2005): 227-242.

Lindeboom, G.A., Herman Boerhaave. The man and his work (London: Methuen, 1968). Lowood, Henry, Patriotism, Profit, and the Promotion of Science in the German Enlightenment (New York: Garland Press, 1991). 
Lucassen, Jan, "Working at the Ichapur Gunpowder Factory in the 179o's, Parts I and II," Indian Historical Review 39 (2012): 19-56, 251-271.

Lucier, Paul, "Court and Controversy: Patenting science in the nineteenth century," British Journal for the History of Science 29 (1996): 139-154.

Lundgren, Anders, "The New Chemistry in Sweden: The debate that wasn't," Osiris 4 (1988): 146-168.

Lynch, Michael, ed., Truth Machine: The contentious history of DNA fingerprinting (Chicago: University of Chicago Press, 2008).

MacKenzie, Donald, Fabian Muniesa and Lucia Siu, eds., Do Economists Make Markets? On the performativity of economics (Princeton: Princeton University Press, 2007).

MacLean, J., "Koperindustrie in Nederland, 1750-1850," Economisch en social-historisch jaarboek 43 (1971): 39-63.

MacLeod, Christine, Inventing the Industrial Revolution. The English patent system (166o180o) (Cambridge: Cambridge University Press, 1988).

Malcolm, Joyce Lee, Guns and Violence: The English experience (Cambridge, MA: Harvard University Press, 2009).

Mallett, Oliver, "Contesting the History of Enterprise and Entrepreneurship," Work, Employment and Society 29 (2015): 177-182.

Malm, Andreas and Alf Hornborg, "The Geology of Mankind? A critique of the Anthropocene narrative," The Anthropocene Review 1 (2014): 62-69.

Markus, Thomas, Buildings \& Power: Freedom and control in the origin of modern building types (London: Routledge, 1993).

Martin Fugier, Anne, La vie élégante ou la formation de Tout-Paris, 1815-1848 (Paris: Fayard, 1990).

Martinón Torres, Marcos, "Inside Solomon's House: An archaeological study of the old Ashmolean chymical laboratory in Oxford," Ambix 59 (2012): 22-48.

Massard Guilbaud, Geneviève, Histoire de la pollution industrielle, France 1789-1914 (Paris: Editions de l'EHess, 2010).

Matthias, Peter, The First Industrial Nation: An economic history of Britain, 1700-1914, second edition (London: Methuen, 1983).

McCosh, Frederic W.J., Boussingault: Chemist and agriculturist (Dordrecht: Kluwer, 1984).

McEvoy, John G., The Historiography of the Chemical Revolution: Patterns of interpretation in the history of science (London: Routledge, 2010).

McKeon, Michael, The Secret History of Domesticity: Public, private, and the division of knowledge (Baltimore: Johns-Hopkins University Press, 2009).

McKie, Douglas, "Priestley's Laboratory and Library and Other of his Effects," Notes and Records of the Royal Society 12 (August 1956): 114-136.

Meinel, Christophe, "Reine und angewandteChemie," BerichtezurWissenschaftsgeschichte 8 (1985): 25-45. 
Melton, James van Horn, The Rise of the Public in Enlightenment Europe (Cambridge: Cambridge University Press, 2001).

Miller, A.H., revised by Ralph Harrington, "Reid, David Boswell (1805-1863)," Oxford Dictionary of National Biography (Oxford: Oxford University Press, 2004).

Miller, David, James Watt, Chemist: Understanding the origins of the steam age (London: Pickering and Chatto, 2009).

Millerand, Florence, 'Les gestionnaires d'information 'invisibles' dans la production d'une base de données scientifiques," Revue d'anthropologie des sciences 6 (2012): 163-190.

Minard, Philippe, "Le métier sans institution: les lois d'Allarde-Le Chapelier de 1791 et leur impact au début du XIX ${ }^{\mathrm{e}}$ siècle," Steven Kaplan and Philippe Minard, eds., La fin des corporations (Paris: Belin, 2003), 81-95.

Misa, Thomas, From Leonardo to the Internet: Technology and culture from the Renaissance to the present (Baltimore: Johns Hopkins University Press, 2004).

Mitchell, Timothy, Carbon Democracy: Political power in the age of oil (London: Verso, 2011).

Mitchell, Timothy, "Rethinking Economy," Geoforum 29 (2008): 1116-1121.

Mitchell, Timothy, Rule of Experts: Egypt, techno-politics, modernity (Berkeley, 2002).

Mody, Cyrus and Michael Lynch, "Test Objects and other Epistemic Things: A history of a nanoscale object," British Journal for the History of Science 43 (2010): 423-458.

Mokyr, Joel, The Enlightened Economy: An economic history of Britain, 1700-1850 (New Haven: Yale University Press, 2009).

Mokyr, Joel, ““Entrepreneurship in the Industrial Revolution,” David Landes, Joel Mokyr and William Baumol, eds., The Invention of Enterprise (Princeton, NJ: Princeton University Press, 2012), 183-210.

Mokyr, Joel, The Gifts of Athena: Historical origins of the knowledge economy (Princeton: Princeton University Press, 2002).

Mol, Annemarie, The Body Multiple: Ontology in medical practice (Raleigh, NC: Duke University Press, 2002).

Moquette, J.P., "De munten van Nederlandsch-Indië," Tijdschrift voor Indische Taal-, Land- en Volkenkunde (1909): 33-96.

Morange, Claude, "Las estructuras de poder en el tránsito del Antiguo al Nuevo Régimen," Joseph Pérez and Armando Alberola, eds., España y América entre la Ilustración y el liberalism (Alicante- Madrid: Casa de Velázquez-Instituto de Cultura Juan Gil-Albert, 1993), 35-7.

Morrell, J.B., "The Chemist Breeders: the Research Schools of Liebig and Thomas Thomson," Ambix 9 (1972): 1-46.

Morrell, J.B., "Practical Chemistry in the University of Edinburgh, 1799-1843," Ambix 16 (1969): 66-8o. 
Morrell, J.B., "Thomas Thomson: Professor of Chemistry and University Reformer," British Journal for the History of Science 4 (1969): 245-286.

Morris, Peter J.T., "The Eighteenth Century: Chemistry allied to anatomy," Robert Williams, Joseph Paton, Allan Chapman, and John Shipley Rowlinson, eds., Chemistry at Oxford: A history from 1600 to 2005 (London: Royal Society of Chemistry, 2008), $5^{2-78 .}$

Morris, Peter J.T., The Matter Factory: A history of the chemistry laboratory (London: Reaktion Books, 2015).

Morris, Peter J.T., Colin Russell and John Smith, Archives of the British Chemical Industry: A handlist (Oxford: British Society for the History of Science, 1988).

Morson, A.F.P., Operative Chymist, Clio Medica no. 45 (Amsterdam: Rodophi, 1997).

Morvan Becker, Frédéric, "Lécole gratuite de dessin de Rouen, ou la formation des techniciens au XVIIIe siècle," PhD thesis, Université Paris VIII-Saint Denis, 2010.

Muir, John, John Anderson, Pioneer of Technical Education and the College He Founded in Glasgow (Glasgow: John Smith \& Son, 1950).

Musson, Albert and Eric Robinson, Science and Technology in the Industrial Revolution (Manchester: Manchester University Press, 1969).

Narbeth, Colin, Robin Hendy and Christopher Stocker, Historische bankbiljetten en aandelen (Baarn: Moussault's Uitgeverij, 1979).

Netscher, Elisa and Jacobus A. van der Chijs, De munten van Nederlands-Indië (Batavia 1863).

Nieto Galàn, Agustí, Colouring Textiles. A history of natural dyesuffs in industrial Europe (Boston: Boston Studies in the Philosophy and History of Science, 2001).

O'Farrell, P.N., Heriot Watt University: An illustrated history (Harlow: Pearson Educational, 2004).

Oreskes, Naomi and Erik Conway, Merchants of Doubt: How a handful of scientists obscured the truth on issues from tobacco smoke to globalwarming (London: Bloomsbury Press, 2010).

Orlikowski, Wanda J. "Sociomaterial Practices: Exploring technology at work," Organization Studies 28 (2007): 1435-1448.

Ozouf, Mona, L’homme régénéré. Essais sur la révolution française (Paris: Gallimard, 1989).

Palladino, Paolo and Michael Worboys, "Science and Imperialism," Isis 84 (1993): 91-102.

Parascandola, John, King of Poisons. A history of arsenic (Washington: Potomac Books, 2012).

Paris, John, The Life of Sir Humphry Davy, 2 volumes (London: Colburn and Bentley, 1831). 
Parker, Harold T., An Administrative Bureau During the Old Regime: The Bureau of Commerce and its relations to French industry from May 1781 to November 1783 (London: Associated University Press, 1993).

Parssinen, Terry M., Secret Passions, Secret Remedies: Narcotic drugs in British society, 1820-1930 (Manchester: MUP, 1983).

Parthasarathi, Prasannan, Why Europe Grew Rich and Asia Did Not: Global economic divergence, 1600-1850 (Cambridge: Cambridge University Press, 2011).

Pascoe, W.H., ccc: The History of the Cornish Copper Company (Hayle: Haylebooks, 1981). Pascual Artiaga, Mercedes, "La ciudad ante el contagio: medidas políticas y administrativas dictadas en la epidemia de fiebre amarilla de 1804 en Alicante," Asclepio 54 (2002): 125-153.

Pennell, Sara, "'Pots and Pans History': The material culture of the kitchen in early modern England," Journal of Design History 11 (1998): 201-216.

Pennell, Sara and Elaine Leong, "Recipe Collections and the Currency of Medical Knowledge in the Early Modern 'Medical Marketplace," Mark Jenner and Patrick Wallis, eds., Medicine and the Market in England and its Colonies, c.1450-c.1850 (Basingstoke: Palgrave Macmillan, 2007), 133-152.

Perkins, John, "Chemistry Courses, the Parisian chemical world and the chemical revolution, 1770-1790," Ambix 57 (2010): 27-47.

Perkins, John, "Creating Chemistry in Provincial France before the Revolution: The examples of Nancy and Metz," Ambix 51 (2004): 4375.

Perkins, John, ed., Sites of Chemistry in the Eighteenth Century, special issue of Ambix 60 (2013).

Perrin, Carleton, "Of Theory Shifts and Industrial Innovations: The relations of J.A.C. Chaptal and A.L. Lavoisier," Annals of Science 43 (1986): 511-542.

Peset, Mariano and José Luis Peset, Muerte en España. Política y sociedad entre la peste y el cólera (Madrid: Seminarios y Ediciones, 1977).

Pierrot, Nicolas, "Les images de l'industrie en France, peintures, dessins, estampes, 17601870," PhD thesis, Université Paris I Panthéon-Sorbonne, 3 vols., 2010.

Pirohakul, Teerapa and Patrick Wallis, "Medical Revolutions? The growth of medicine in England, 1660-1800," Journal of Social History 49 (2016): 510-531.

Pissarello, Giulia. "Industrialism as "Tragedy of Ugliness": D.H. Lawrence's ecological consciousness," Griseldaonline 10 (2011): 31-42.

Planchon, Gustave, L'enseignement des sciences physico-chimiques au Jardin des apothicaires et à l'École de pharmacie de Paris (Paris: Imprimerie Ernest Flammarion, 1897).

Plessis, Alain, ed., Naissances des libertés économiques, 1791-fin XIXe siècle (Paris: Institut d'histoire de l'industrie, 1993).

Pomeranz, Kenneth, The Great Divergence: China, Europe and the making of the modern world economy (Princeton: Princeton University Press, 200o). 
Porter, Roy and Dorothy Porter, "The Rise of the English Drugs Industry: The role of Thomas Corbyn," Medical History 33 (1989): 277-95.

Porter, Theodore, Trust in Numbers: The pursuit of objectivity in science and public life (Princeton: Princeton University Press, 1995).

Potofsky, Allan, "Recycling the City: Paris, 1760s-180o," Ariane Fennetaux, Amélie Junqua and Sophie Vasset, eds., The Afterlife of Used Things: Recycling in the long eighteenth century (New York: Routledge, 2015), 71-88.

Powers, John C., "Leiden Chemistry in Edinburgh: Herman Boerhaave, James Crawford and Andrew Plummer," R.G.W. Anderson, ed., Cradle of Chemistry: The early years of chemistry at the University of Edinburgh (Edinburgh: John Donald, 2015), 25-58.

Principe, Lawrence M., "Apparatus and Reproducibility in Alchemy," Frederic L. Holmes and Trevor H. Levere, eds., Instruments and Experimentation in the History of Chemistry (Cambridge, MA: MIT Press, 2000), 55-74.

Pritchard, Sara B., "Mining Land and Labor," Environmental History, 10 (2005): 731-733.

Puig Pla, Carlos, "Els primers socis-artistes de la Reial Acadèmia de Ciències i Arts de Barcelona (1746-1842)," Agustí Nieto Galán and Antoni Roca Rosell, eds., La Reial Acadèmia de Cièncias $i$ Arts de Barcelona als segles XVIII y XIX. Història, ciència $i$ societat (Barcelona: Institut d'Estudis Catalans, 2000), 287-310.

Puigvert, Joaquim, ed., Bisbes, Illustració i jansenisme a la Catalunya del segle XVIII (Vic: Biblioteca Universitaria, 200o).

Pyenson, Lewis, Empire of Reason. Exact sciences in Indonesia 1840-1940 (Leiden: Brill, 1989).

Quarrell, W.H. and Margaret Mare, eds., London in 1710 from the Travels of Zacharius Conrad von Uffenbach (London: Faber and Faber, 1934).

Queruel, Alain, Vauquelin et son temps (1763-1829) (Paris: L'Harmattan, 1994).

Rainhorn, Judith, "La santé au risque du marché, Savoir médical, concurrence économique et régulation des risques entre blanc de zinc et blanc de plomb (France XIX ${ }^{\mathrm{e}}$ siècle)," Thomas Le Roux, ed., Risques et accidents industriels, fin XVIIe-fin XIXe siècles (Rennes: Presses universitaires de Rennes, 2016).

Ramsay, William, The Life and Letters ofJoseph Black (London: Constable, 1918).

Rappert, Brian, “Technologies, Texts, and Possibilities: A reply to Hutchby," Sociology 37 (2003): 565-80.

Reichardt, Rolf and H.J. Lüsebrink, "Révolution à la fin du $18^{\mathrm{e}}$ siècle. Pour une relecture d'un concept-clé du siècle des Lumières," Mots 16 (1988): 35-68.

Rey, Alain, Révolution: Histoire d'un mot (Paris: Gallimard, 1989).

Rheinberger, Hans Jörg, "Experiment, Différence and Writing I," Studies in History and Philosophy of Science 23 (1992): 305-331.

Rheinberger, Hans Jörg, "A Reply to David Bloor: 'Toward a sociology of epistemic things,", Perspectives on Science 13 (2005): 406-410. 
Rheinberger, Hans Jörg, Toward a History of Epistemic Things (Palo Alto: Stanford University Press, 1997).

Richmond, Lesley, Julie Stevenson and Alison Turton, eds., The Pharmaceutical Industry: A guide to historical records (Aldershot: Ashgate, 2003).

Riedman, Sarah Regal, Antoine Lavoisier: Scientist and citizen (London: Schuman, 1967). Rip, Arie, "De Facto Governance of Nanotechnologies," Morag Goodwin, Bert-Jaap Koops, and Ronald Leenes, eds., Dimensions of Technology Regulation (Nijmegen: Wolf Legal Publishers, 2010), 285-308.

Roberts, Lissa L., "Accumulation and Management in Global Historical Perspective: An introduction," History of Science $5^{2}$ (2014): 227-246.

Roberts, Lissa L., "Le centre de toutes choses': Constructing and managing centralization on the Isle de France," History of Science $5^{2}$ (2014): 319-342.

Roberts, Lissa L., "Condillac, Lavoisier, and the Instrumentalization of Science," Eighteenth-Century: Essays and interpretation 33 (1992): 252-271.

Roberts, Lissa L., "The Death of the Sensuous Chemist: The 'new' chemistry and the transformation of sensuous technology," Studies in History and Philosophy of Science Part A 4 (1995): 503-529.

Roberts, Lissa L., "Exploring Global History Through the Lens of History of Chemistry: Materials, identities and governance," History of Science 54 (2016): 335-361.

Roberts, Lissa L., "Geographies of Steam: Mapping the entrepreneurial activities of steam engineers in France during the second half of the eighteenth century," History and Technology 27 (2011): 417-439.

Roberts, Lissa L., "P.J. Kasteleyn and the "Oeconomics" of Dutch Chemistry," Ambix 53 (2006): 255-272.

Roberts, Lissa L., "Practicing Oeconomy During the Second Half of the Long Eighteenth Century: An introduction," History and Technology 30 (2014): 133-148.

Roberts, Lissa L., ed., Practicing Oeconomy in the late Eighteenth Century, Special issue of History and Technology 30 (2014): 133-279.

Roberts, Lissa L., "Producing (in) Europe and Asia, 1750-1850," Isis 106 (2015): 857-865.

Roberts, Lissa L., "A Word and the World: The significance of naming the calorimeter," Isis 82 (1991): 199-222.

Roberts, R.S., "The Early History of the Import of Drugs into Britain," F.N.L. Poynter, ed., The Evolution of Pharmacy in Britain (London: Pitman, 1965), 165-185.

Robinson, Eric, and Douglas McKie, eds., Partners in Science: Letters of James Watt and Joseph Black (London: Constable, 1970).

Roche, Daniel, "Encyclopedias and the Diffusion of Knowledge," Mark Goldie and Robert Wokler, eds., The Cambridge History of Eighteenth-Century Political Thought (Cambridge: Cambridge University Press, 2006), 172-194.

Rodríguez Ocaña, Esteban, "La cuestión del lazareto marítimo permanente en la España del siglo XVIII, de Cádiz a Mahon," Asclepio 40 (1988): 265-276. 
Rotherham, Ian D. and David McCallam, "Peat Bogs, Marshes and Fens as Disputed Landscapes in Late Eighteenth-Century France and England," Louise Lyle and David McCallam, eds., Histoires de la Terre: Earth sciences and French culture 1740-1940 (Amsterdam: Rodopi, 2008), 75-88.

Rouff, Marc, Les mines de charbon en France au XVIIIe siècle (Paris: Rieder et Cie, 1922). Rouffaer, Gerret P., De voornaamste industrieën der inlandsche bevolking van Java en Madoera ('s-Gravenhage: Martinus Nijhoff, 1904).

Rowlinson, John, Sir James Dewar, 1842-1923: A ruthless chemist (Farnham: Ashgate, 2012). Russell, Ben, James Watt: Making the world anew (London: Reaktion, 2014).

Russell, Colin A., Noel G. Coley and Gerrylynn K. Roberts, Chemists by Profession. The origins and rise of the Royal Institute of Chemistry (Milton Keynes: Open University Press, 1977).

Ruston, Sharon, "From "The Life of the Spinosist" to "Life": Humphry Davy, chemist and poet," Margaret Hagen and Margery Skagen, eds., Literature and Chemistry: Elective affinities (Aarhus: Aarhus University Press, 2013), 77-97.

Sadoun Goupil, Michelle, Le chimiste C.L. Berthollet, 1748-1822, sa vie, son oeuvre (Paris: Vrin, 1977).

Schabas, Margaret and Neil Di Marchi, "Introduction to Oeconomies in the Age of Newton," Margaret Schabas and Neil Di Marchi, eds., Oeconomies in the Age of Newton. Annual Supplement to History of Political Economy 35 (2003): 1-13.

Schabas, Margaret, The Natural Origins of Economics (Chicago: University of Chicago Press, 2005).

Schaffer, Simon, "Assay Instruments and the Geography of Precision on the Guinea Trade," Marie-Noëlle Bourget, Christian Licoppe and H. Otto Sibum, eds., Instruments, Travel and Science. Itineraries of precision from the seventeenth to the twentieth century (London: Routledge, 2002), 20-50.

Schaffer, Simon, "'The Charter'd Thames': Naval architecture and experimental spaces in Georgian Britain," Lissa Roberts, Simon Schaffer and Peter Dear, eds., The Mindful Hand: Inquiry and invention from the late Renaissance to early industrialisation (Amsterdam: Royal Netherlands Academy of Arts and Sciences, 2007), 279-305.

Schaffer, Simon, "Measuring Virtue: Eudiometry, enlightenment and pneumatic medicine," Andrew Cunningham and Roger French, eds., The Medical Enlightenment of the Eighteenth Century (Cambridge: Cambridge University Press, 1990), 281-318.

Schaffer, Simon, "Natural Philosophy and Public Spectacle in the Eighteenth Century," History of Science 21 (1983): 1-43.

Schatzberg, Eric, “From Art to Applied Science," Isis 103 (2012): 555-563.

Scheffers, Albert A. J., "Om de kwaliteit van het geld. Het toezicht op de muntproductie in de Republiek en de voorziening van kleingeld in Holland and West-Friesland in de achttiende eeuw," PhD Thesis, Leiden University, 2013. 
Scheffers, Albert A. J., "Johan Sebastiaan van Naamen, Muntmeester van Batavia 17641768 en Utrecht 1782-1797 in Perspectief," De Muntkoerier 42:11 (2013): 18-19.

Schofield, Robert E., The Enlightened Joseph Priestley: A study of his life and work from 1773 to 1804 (University Park: Pennsylvania State University Press, 2004).

Scholten, Cornelis, De munten van de Nederlandsche gebiedsdelen overzee, 1601-1948 (Amsterdam:J. Schulman, 1951).

Schrader, Astrid, "Responding to Pfiesteria Piscicida (The Fish Killer): Phantomatic ontologies, indeterminacy, and the responsibility in toxic microbiology," Social Studies of Science 40 (2010): 275-306.

Schrøder, Michael, The Argand Burner: Its origin and development in France and England, 1780-1800: an epoch in the history of science illustrated by the life and work of the physicist Ami Argand, 1750-1803 (Odense: Odense University Press, 1969).

Schumpeter, Joseph, Capitalism, Socialism and Democracy (New York: Harper, 2008).

Selin, Henrik, Global Governance of Hazardous Chemicals: Challenges of multilevel management (Cambridge: MIT Press, 2010).

Serrano, Elena, "Chemistry in the City: The scientific role of female societies in late eighteenth-century Madrid," Ambix 60 (2013): 139-159.

Serrano, Elena, "Making Oeconomic People: The Spanish Magazine of Agriculture and Arts for Paris Rectors (1797-1808)," History and Technology 30 (2014): 149-176.

Sewell, William, "Visions of Labour: Illustrations of the mechanical arts before, in and after Diderot's Encyclopédie," Steven Kaplan and Cynthia Koepp, eds., Work in France. Representations, meaning, organization and practice (Ithaca: Cornell University Press, 1986), 258-286.

Shapin, Steven, "The House of Experiment in 17th-Century England," Isis 79 (1988): 373-404.

Shapin, Steven, “The Invisible Technician," American Scientist 77 (1989): 554-63.

Shapin, Steven and Simon Schaffer, Leviathan and the Air Pump: Hobbes, Boyle, and the experimental life (Princeton: Princeton University Press, 1985).

Sibum, H. Otto, "Les gestes de la mesure. Joule, les pratiques de la brasserie et la science," Annales. Histoire, sciences sociales 4-5 (1998): 745-774.

Simmons, Anna, "Medicines, Monopolies and Mortars: The chemical laboratory and the pharmaceutical trade at the Society of Apothecaries in the eighteenth century," Ambix 53 (2006): 221-36.

Simmons, Anna, "Stills, Status, Stocks and Science: The laboratories at Apothecaries' Hall in the nineteenth century," Ambix 61 (2014): 141-161.

Simon, Jonathan, Chemistry, Pharmacy and Revolution in France, 1777-1809 (Aldershot: Ashgate, 2013).

Simon, Jonathan, "La chimie et la pharmacie en 1800," Revue d'Histoire de la Pharmacie 49 (2001): 175-182. 
Slater, A.W., "Howards, Chemical Manufacturers, 1797-1837: A study in business history," M.Sc. Econ. Thesis, London University, 1956.

Slater, A.W., ed., "Autobiographical Memoir of Joseph Jewell, 1763-1846," Camden Miscellany 22 (1964): 113-78.

Slijkhuis, Henri, De kopermolen in Zuuk (Vorchten: De Bekenstichting, 2015).

Slinn, Judy, "Research and Development in the UK Pharmaceutical Industry from the Nineteenth Century to the 1960s," Mikuláš Teich and Roy Porter, eds., Drugs and Narcotics in History (Cambridge: Cambridge University Press, 1995), 168-186.

Smeaton, William A., "Guyton de Morveau, Louis Bernard," Charles C. Gillispie, ed., Dictionary of Scientific Biography (New York: Cribner, 1976), 60o-604.

Smeaton, William A., "Platinum and Ground Glass: Some innovations in chemical apparatus by Guyton de Morveau and others," Frederic L Holmes and Trevor H. Levere, eds., Instruments and Experimentation in the History of Chemistry (Cambridge: MIT Press, 2000), 211-238.

Smith, Annette M., "State Aid to Industry: An eighteenth-century example," T.M. Devine, ed., Lairds and Improvement in the Scotland of the Enlightenment (Glasgow: 9th Scottish Historical Conference, 1978), 21-30.

Smith, John Graham, The Origins and Early Development of Heavy Chemical Industry in France (Oxford: Clarendon Press, 1979).

Smith, Michael Stephen, The Emergence of Modern Business Enterprise in France (Cambridge, MA: Harvard University Press, 2005).

Sobieniak, Chantal, Rebondissements dans l'affaire Lafarge (Paris: Lucien Souny, 2010). Spang, Rebecca, Stuff and Money in the Time of the French Revolution (Cambridge, MA: Harvard University Press, 2015).

Speight, James G., The Chemistry and Technology of Coal (Boca Raton: Taylor and Francis, 2013).

Stander, S., "Transatlantic Trade in Pharmaceuticals during the Industrial Revolution," Bulletin of the History of Medicine 43 (1969): 326-343.

Stander, Simon S., "A History of the Pharmaceutical Industry with Particular Reference to Allen and Hanbury, 1775-1843," M.Sc. Econ. Thesis, London University, 1965.

Stansfield, Dorothy, Thomas Beddoes M.D., 1760-1808: Chemist, physician, democrat (Dordrecht: Reidel, 1984).

Star, Susan Leigh and James Grisemer, 'Institutional Ecology, 'Translations' and Boundary Objects: Amateurs and professionals in Berkeley's Museum of Vertebrate Zoology, 1907-39," Social Studies of Science 19 (1998): 387-420.

Steele, I.K., Atlantic Merchant Apothecary: Letters ofJoseph Cruttenden, 1710-1717 (Toronto: University of Toronto Press, 1977).

Steffen, Will, Jacques Grinevald, Paul Crutzen and John McNeill, "The Anthropocene: Conceptual and historical perspectives," Philosophical Transactions of the Royal Society A 369 (2011): 842-867. 
Stein, Claudia, "The Birth of Biopower in Eighteenth-Century Germany," Medical History 55 (2011): 331-37.

Stevens, Thomas, Van der Capellen's koloniale ambitie op Java. Economisch beleid in een stagnerende conjunctuur, 1816-1826 (Amsterdam, 1982).

Stewart, Larry, "Ordinary' People and Philosophers in the Laboratories and Workshops of the Early Industrial Revolution," Margareth C. Jacob and Catherine Secretan, eds., In Praise of Ordinary People: Early modern Britain and the Dutch Republic (New York: Palgrave Macmillan, 2013), 95-122.

Stiles, Margaret, "The Quakers in Pharmacy," F.N.L. Poynter, ed., The Evolution of Pharmacy in Britain (London: Pitman, 1965), 113-30.

Stockland, Etienne, "La guerre aux insectes': Pest control and agricultural reform in the French enlightenment," Annals of Science 70 (2013): 435-46o.

Sutton, Geoffroy, Science for a Polite Society: Gender, culture, and the demonstration of enlightenment (Colorado: Westview Press, 1995).

Swann, John P., “The Pharmaceutical Industries," Peter J. Bowler and John V. Pickstone, eds., The Cambridge History of Science Volume 6: Modern Life and Earth Sciences (Cambridge: Cambridge University Press, 2009), 126-140.

Tana, Li, "Cochinchinese Coin Casting and Circulating in Eighteenth-Century Southeast Asia," Eric Tagliacozzo and Wen-chin Chang, eds., Chinese Circulations. Capital, commodities, and networks in Southeast Asia (Durham: Duke University Press, 2011), 130-148.

Taylor, George V., “Types of Capitalism in Eighteenth-Century France," The English Historical Review 79 (1964): 478-97.

Taylor, J.G., The Social World of Batavia. Europeans and Eurasians in colonial Indonesia (Madison: University of Wisconsin Press, 2009).

Thébaud Sorger, Marie, L'aérostation au temps des lumières (Rennes: Presses Universitaires de Rennes, 2009).

Thébaud Sorger, Marie, "Amitiés, entraides et circulations techniques: les affinités électives de l'entrepreneur Argand," Michel Cotte, ed., Circulations techniques, en amont de l'innovation: Hommes, objets et idées en mouvement (Montbeliard: Presses Universitaires de Franche-Comté - Ut Belfort-Montbéliard, 2004), 111-128.

Thébaud Sorger, Marie, "Innovation and Risk Management in Late Eighteenth-Century France: The administration of inventions in French cities at the end of the ancien régime," Christelle Rabier, ed., Fields of Expertise. A comparative history of expert procedures in Paris and London. 1600 to present (Cambridge: Cambridge Scholar Press, 2007), 261-289.

Todericu, Doru, "Les mines du pays de Liège dans les papiers du savant Français Jean Hellot (1685-1766)," Technologia 6 (1983): 61-68.

Tomic, Sacha, "Le cadre matériel des cours de chimie dans l'enseignement supérieur à Paris au XIX ${ }^{\mathrm{e}}$ siècle," Histoire de l'éducation 130 (2011): 57-83. 
Tomic, Sacha, Comment la chimie a transformé le monde. Une histoire en sept tableaux (Paris: Le Square, 2013).

Tomic, Sacha, Aux origines de la chimie organique. Méthodes et pratiques des pharmaciens et des chimistes (1785-1835) (Rennes: Presses Universitaires de Rennes, 2010).

Tomory, Leslie, Progressive Enlightenment: The origins of the gaslight industry, 1780-1820 (London; Cambridge, MA: MIT Press, 2012).

Traill, Thomas, "Memoir of Dr. Thomas Charles Hope, late Professor of Chemistry in the University of Edinburgh," Transactions of the Royal Society of Edinburgh 16 (1848): 419-434.

Travis, N.J. and E.J. Cocks, The Tincal Trail: A history of borax (London: Harrap, 1984).

Tresch, John, The Romantic Machine. Utopian science and technology after Napoleon (Chicago: University Press, 2012).

Tribe, Keith, "Oeconomic History: An essay review," Studies in the History and Philosophy of Science 36 (2005): 586-597.

Trompette, Pascale and Mélanie Lemonnier, "Funeral Embalming: The transformation of a medical innovation," Science Studies 22 (2009): 9-30.

Tweedale, Geoffrey, At the Sign of the Plough: Allen and Hanburys and the British pharmaceutical industry, 1715-1990 (London: John Murray, 1990).

Uittenbogaard, Roland. Evolution of Central Banking? De Nederlandsche Bank 1814-1852 (Dordrecht: Springer, 2015).

Underwood, E.A., Cecil Wall and H.C. Cameron, eds., A History of the Worshipful Society of Apothecaries of London, vol. 1, 1617-1815 (London: Oxford University Press, 1963).

Viallaneix, Paul and R. Elmoznino, eds., L'apprentissage du savoir savant (Paris: PUF, 1995).

Vickery, Amanda, Behind Closed Doors: At home in Georgian England (New Haven: Yale University Press, 2009).

Vries, B.W. de, De Nederlandse papiernijverheid in de negentiende eeuw ('s-Gravenhage: Martinus Nijhoff, 1957).

Vries, Jan de, Consumer Behavior and the Household Economy, 1650 to the Present (Cambridge: Cambridge University Press, 2008).

Waal, A.M. van de, "De oudste bankbiljetten. Eerste relatie van de Nederlandsche Bank met Joh. Enschedé en Zonen," Ontwikkelings- en ontspanningsvereniging "De Nederlandsche Bank" 8 (1953): 4-14.

Wachsmuth, David, “Three Ecologies: Urban metabolism and the society-nature divide," The Sociological Quarterly 53 (2012): 506-523.

Wakefield, Andre, "Police Chemistry," Science in Context 13 (2000): 231-267.

Walker, Brett, Toxic Archipelago: A history of industrial disease in Japan (Seattle: University of Washington Press, 2010).

Wallis, Patrick, "Exotic Drugs and English Medicine: England's drug trade, c.1550 c.180o," Social History of Medicine 25 (2012): 20-46. 
Wallis, Patrick, "Medicines for London: The trade, regulation and lifecycle of London apothecaries c.1610-1670," PhD Thesis, Oxford University, 2002.

Ward, Candance, Desire and Disorder: Fevers, fictions, and feelings in English Georgian Culture (Lewisburg: Bucknell University Press, 2007).

Watson, G.M., "Some Eighteenth Century Trading Accounts," F.N.L. Poynter, ed., The Evolution of Pharmacy in Britain (London: Pitman, 1965), 45-78.

Watson, Katherine, Poisoned Lives: English poisoners and their victims (London: Hambledon, 2004).

Weber, A. "Bitter Fruits of Accumulation: the Case of Caspar Georg Carl Reinwardt (1773-1854)," History of Science $5^{2}$ (2014): 297-318.

Werrett, Simon, "From the Grand Whim to the Gasworks: Philosophical fireworks in Georgian England," Lissa Roberts, Simon Schaffer and Peter Dear, eds., The Mindful Hand: Inquiry and invention from the late Renaissance to early industrialisation (Amsterdam: Royal Netherlands Academy of Arts and Sciences, 2007), 325-348.

Werrett, Simon, "Matter and Facts: Material culture and the history of science," Robert Chapman and Alison Wylie, eds., Material Evidence: Learning from archeological practice (London: Routledge, 2015), 339-351.

Werrett, Simon, "Recycling in Early Modern Science," British Journal for the History of Science 46 (2013): 627-646.

Werrett, Simon, Thrifty Science (Chicago: University of Chicago Press, forthcoming).

Whorton, James C., The Arsenic Century: How Victorian Britain was poisoned at home, work, and play (Oxford: Oxford University Press, 2010).

Wigelsworth, Jeffrey R., Selling Science in the Age of Newton: Advertising and the commoditization of knowledge (Farnham: Asghate, 2010).

Wylie, Alison and Robert Chapman, eds. Material Evidence:Learning from archaeological evidence (London: Routledge, 2014).

Wille, Robert-Jan, "The Coproduction of Station Morphology and Agricultural Management in the Tropics: Transformations in botany at the botanical garden at Buitenzorg, Java 1880-1904," Denise Phillips and Sharon Kingsland, eds., New Perspectives on the History of Life Sciences and Agriculture (Dordrecht: Springer, 2015), 253-275.

Williams, Michael, Deforesting the Earth: From prehistory to global crisis (Chicago: University of Chicago Press, 2003).

Willies, Lynn, "Derbyshire Lead Mining in the Eighteenth and Nineteenth Centuries," Mining History 14 (1999): 31-33.

Wilson, Renate, "Trading in Drugs through Philadelphia in the Eighteenth Century: A transatlantic enterprise," Social History of Medicine 26 (2013): 352-363.

Withers, Charles, Urban Highlanders: Highland-lowland migration and urban Gaelic culture, 1700-19oo (East Linton: Tuckwell Press, 1998). 
Wolfe, John, Brandy, Balloons, and Lamps: Ami Argand, 1750-1803 (Carbondale: Southern Illinois University Press, 1999).

Wolters, Willem G., "The 'Doit Infestation in Java': Exchange rates between silver and copper coins in Netherlands India in the period, 1816-1854," Hans Ulrich Vogel, ed., Money in Asia (1200-19oo): Small currencies in social and political contexts (Leiden: Brill, 2015), 108-139.

Woolgar, Steve and Daniel Neyland, Mundane Governance: Ontology and accountability (Oxford: Oxford University Press, 2015).

Wrigley, E.A., Continuity, Chance and Change: The character of the industrial revolution in England (Cambridge: Cambridge University Press, 1988).

Wrigley, E.A., Energy and the English Industrial Revolution (Cambridge: Cambridge University Press, 2010).

Zappey, W.M., De economische en politieke werkzaamheid van Johannes Goldberg (Brussel: N. Samson, 1967). 